\title{
"ESTÉTICA DE LO TREMENDO, DEL HORROR Y DEL ESPANTO": UN INÉDITO CRUCIFICADO NOVOHISPANO EN UNA COLECCIÓN PARTICULAR DE SANLÚCAR DE BARRAMEDA (CÁDIZ)
}

\author{
"TREMENDOUS, HORROR AND FRIGHT AESTHETICS": \\ AN UNPUBLISHED NEW HISPANIC CRUCIFIED CHRIST \\ IN A SANLÚCAR DE BARRAMEDA (CADIZ) PRIVIT \\ COLLECTION
}

\author{
Álvaro Recio Mir \\ Universidad de Sevilla. España \\ alvarorecio@us.es \\ Jesús Morejón Pazos \\ jmorejonp@hotmail.com
}

Análisis de una inédita escultura de Cristo Crucificado, de pequeño formato y procedencia novohispana en una colección particular de Sanlúcar de Barrameda, Cádiz, que cabe fechar en la segunda mitad del siglo XVIII. Lo más llamativo de la obra es el desarrollo de todo un repertorio de cruentas heridas que son interpretadas en relación con otras imágenes virreinales de similar factura, tanto escultóricas como pictóricas.

Palabras clave: Escultura, Cristo Crucificado, Nueva España, Siglo XVIII, iconografía.

Analysis of an unpublished sculpture of Crucified Christ, of small format and New Spanish origin in a Sanlúcar de Barrameda's private collection (Cadiz) which is possible to date in the second half of the 18th century. The most interesting of the work is the development of the whole digest of bloody wounds that they are interpreted in relation by other viceroyalty images of similar invoice, both sculptural and pictorial.

Keywords: Sculpture, Crucified Christ, New Spain, 18th century, iconography.

Damos a conocer en estas páginas una escultura de Cristo Crucificado de procedencia novohispana y aparecida recientemente en una colección particular 
de la localidad de Sanlúcar de Barrameda (Cádiz). La factura de la obra, así como su calidad artística y sus sorprendentes cualidades expresivas invitan a incidir, una vez más, en la rica coyuntura artística novohispana del siglo XVIII, así como en su proyección metropolitana. (Figura 1).

Se trata de una obra de pequeño formato, apenas un pie de altura, lo que nos hace suponer que debió de ser una imagen de devoción privada de carácter doméstico. En este sentido, cabe recordar la abundancia de piezas similares que aparecen referidas en los inventarios de palacios y grandes casas novohispanas, dispuestas tanto en los oratorios de las mismas como en otras estancias, protegidos por fanales o "escaparates" o ubicados directamente sobre bufetes u otros muebles ${ }^{1}$. De igual manera, contamos con ejemplos metropolitanos similares, alguno de ellos particularmente relacionado con el que en esta ocasión traemos a colación, como las esculturas de San Miguel, San José y, sobre todo, de Cristo Crucificado de una colección particular de El Puerto de Santa María -muy próxima por tanto a la localidad donde se encuentra la imagen que ahora analizamos-, que dio a conocer y analizó con particular brillantez Gómez Piñol, también de procedencia novohispana ${ }^{2}$.

La obra que ahora presentamos es de una factura perfectamente terminada, lo que pone en evidencia que se trataba de una obra per se y no un modellino, boceto o paso previo de otra escultura de mayor tamaño o distinto material. De igual manera, su pequeño formato prueba su referida finalidad privada y aleja la posibilidad de que tenga que ver con otras formas de culto, como son los crucificados de altar o de púlpito, tipologías ambas por lo general de un tamaño mayor que éste ${ }^{3}$.

El Crucificado que nos ocupa es fijado en una peana de caoba de sobrias líneas neoclásicas, por lo que la suponemos posterior a la imagen, quizá del siglo XIX. Cabe imaginar que en origen, como ocurre en otros casos, su peana simularía rocas,

${ }^{1}$ Un ejemplo de estas viviendas es analizado en ESCOBOSA DE RANGEL, Magdalena: El palacio de los condes de Heras Soto, sede del Archivo Histórico de la Ciudad de México. México, 2011.

2 GÓMEZ PIÑOL, Emilio: "Tres esculturas novohispanas inéditas de mediados del siglo XVIII", Buenavista de Indias, 7, 1992, pp. 6-15. Distintos inventarios históricos en Sevilla con obras procedentes de América son recogidos, por ejemplo, en RODA PEÑA, José: "Los bienes artísticos de Diego de Paiva, un comerciante portugués en la Sevilla del siglo XVII", Atrio, 13-14, 2007-2008, pp. 133-160 y en QUILES GARCÍA, Fernando: Sevilla y América en el Barroco, comercio, ciudad y arte. Sevilla, 2009. Sobre este asunto también recomendamos NALLE, Sara T.: "Private devotion, personal space. Religious images in domestic contex", en La imagen religiosa en la Monarquía hispánica. Usos y espacios. Madrid, 2008, pp. 255-272.

3 Sobre estas y otras tipologías de crucificados remitimos a GÓMEZ PIÑOL, Emilio: La iglesia colegial del Salvador. Arte y sociedad en Sevilla (siglos XIII al XIX). Sevilla, 2000, pp. 417-420. 
como si del Gólgota se tratase. En cualquier caso, este Cristo es una escultura de madera tallada y policromada. Está compuesta por tres piezas principales: los brazos y el cuerpo, aunque en las piernas las pantorrillas y los pies son piezas unidas mediante ensambles. La madera tiene un corte tangencial, por lo que la dirección de la veta es vertical. Este soporte lígneo es de color anaranjado oscuro, por lo que pudiera tratarse de una madera dura tropical. Recibió un delicado trabajo de gubia, que cabría calificar en ciertos detalles de virtuoso teniendo en cuenta sobre todo su pequeño formato, lo que es facilitado por ser una madera de fibra cerrada y recta, detalles estos últimos que evitan que se desgarre. Además, y sumado a lo anterior, su madera es de textura suave y uniforme.

Por lo que se refiere a su policromía, la escultura está encarnada al óleo y bruñida a vejiga, sobre una preparación de yeso y cola animal. Esta terminación, brillante, luminosa y considerablemente aporcelanada, es propia de las imágenes de bien entrado el siglo XVIII, todo lo cual potencia su belleza. Del tono general claro de su encarnadura apenas destacan unos sutiles matices verdosos en las heridas y los hematomas del Señor, así como el color rojo de la sangre que emana de las llagas. Pero, sin duda, la particularidad de esta policromía se encuentra en las heridas del cuerpo, cuya verosimilitud se consigue aplicando sobre las oquedades de las mismas trozos de piel natural de color rojo e incluso huesos de animales. En efecto, las heridas siguen un mismo patrón de ejecución: unos trozos de piel, posiblemente vitela, rodean el perímetro de las llagas y recrean el borde de la epidermis humana, levantada tras la contusión o el desgarro causado por la flagelación. El encrespado borde de estas heridas está pintado de color verde con algunos matices violáceos, mientras que las enormes aperturas de las mismas imitan con varios tonos de rojo la sangre, que en ocasiones desciende sobre el cuerpo. Se produce así un áspero efecto de desgarrador dramatismo para conmover al devoto, cumpliendo a la perfección el ideario barroco de llevar a la piedad mediante el ejemplo que aporta la imagen.

En cualquier caso, la zona más impactante la encontramos en la espalda del Crucificado, donde el escultor levantó por completo la piel para presentar dos grandes oquedades torácicas que dejan a la vista cuatro costillas, realizadas con los referidos huesos de animales. Para aumentar, si cabe, el dramatismo, estas costillas fueron pintadas en color rojo imitando la sangre. Ello supone una recreación tan dura como escalofriante que llama poderosamente la atención del receptor de la imagen. (Figura 2).

Resulta impactante que en un cuerpo, de tono general considerablemente clásico, hasta apolíneo podríamos decir, haya catorce heridas, sin contar las dos grandes de los costados de la espalda referidas, las cueles se reparten por el pómulo, hombro y el codo izquierdos, el pectoral derecho, el costado izquierdo, el muslo derecho, ambas rodillas y piernas, el muslo izquierdo trasero y, por último, tres en la espalda, punto donde se alcanza el mayor expresionismo de la obra. No todas las heridas que forman esta constelación dolorosa alcanzan el dramatismo 
de los dos primeros casos referidos, aunque la mayoría de ellas son de carácter abierto y sangrante. (Figura 3).

Otra cuestión inquietante es el contraste que se produce entre el referido y apolíneo cuerpo y la desgarradora cabeza de la imagen. Sin duda, en ella se ha buscado más el patetismo que la belleza, lo que no impide poner en evidencia que a pesar de su diminuto tamaño cuenta con notas de sorprendente virtuosismo, como ojos de vidrio que apenas se ven al estar entornados los párpados. De igual modo, el trabajo de la gubia a la hora de articular la cabellera está notablemente cuidado, igual que ocurre en la barba. No obstante, lo más llamativo es que la imagen general de la cabeza es de un enorme patetismo, como si se inspirase en los tradicionales crucificados dolorosos del final de la Edad Media. Ello es debido, en primer lugar, a que está literalmente hundida en los hombros, lo cual le resta airosidad a la figura. También el hecho de que los pómulos estén marcadamente abultados le da un aspecto cadavérico, a lo que le añade dramatismo que tanto las cejas como los ojos se dispongan caídos. (Figura 4).

Por otro lado, esta escultura cuenta con aplicaciones de diversos elementos de plata. En concreto, son una ancha corona de espinas que circunda la cabeza del Salvador y que está enlazada a las tres potencias que lo rematan. También es de plata labrada el titulus crucis, sobre el que volveremos más adelante y en el que se lee claramente "INRI". Del mismo metal son los tres clavos que anclan el cuerpo de Cristo a la cruz. Estos cinco elementos, más que responder al intenso gusto ornamental del arte virreinal, lo hacen más bien a su ancestral sentimiento religioso, constante en la escultura devocional novohispana, y que se cifra en una evidente propensión al pletórico alajamiento de las imágenes sagradas. Ya fray Toribio de Benavente, apenas dos décadas después de la conquista de Tenochtitlán, señaló al respecto en sus Memoriales que "en los retablos, que no son pocos, ponían a las imágenes diademas de hoja de oro"4. Tales elementos además subrayan los centros de atracción simbólica de las imágenes sagradas, de manera que dirigen al fiel en su percepción de la obra.

Algo similar podríamos decir de la cruz sobre la que lógicamente la figura de Cristo está clavada. Se trata de una robusta y áspera cruz arbórea, de tanta significación en el arte novohispano. No hace falta insistir demasiado, por conocida, en la enorme significación que este símbolo sagrado cobró desde el inicio mismo de la Conquista en la América virreinal. La riqueza y variedad de las cruces novohispanas ya fueron destacadas por los referidos Memoriales de Motolinía, cuando describió tanto la gran devoción que se les profesaba, como la variedad de los materiales con los que estaban realizadas, no faltando las de turquesa, oro,

${ }^{4}$ La cita la tomamos de GÓMEZ PIÑOL, Emilio: “Tres esculturas novohispanas...”, op. cit., pp. 7 y 8. 
plata o plumas ${ }^{5}$. En nuestro caso, la cruz, cuya madera está pintada en un tono general muy oscuro, cuenta con contrastados detalles dorados allí donde se simula que se ha perdido la originaria corteza del árbol, conseguidos mediante la aplicación de panes de oro fino sin bruñir.

No obstante, es el cuerpo de Cristo lo más significativo de la obra. Sin duda, su tipología responde a los heroicos modelos de signo renacentista, caracterizados por su estilización y olímpica belleza, que se difundieron a lo largo del siglo XVI. El gusto por resaltar las cuidadas proporciones del cuerpo humano desnudo llevó a su anónimo autor a reducir el perizonium que púdicamente cubre la desnudez del cuerpo del Señor a su mínima expresión, sostenido por dos vueltas de soga, y a dejar prácticamente expedita una de sus caderas, logrando así revelar casi por completo el desnudo y elegante perfil de la figura. Sin duda, pese a su referido pequeño formato, su anónimo autor consiguió realizar una obra auténticamente monumental y de imponente apariencia.

Verdaderamente llamativo nos resulta la visión de perfil de la imagen, ya que lejos de resultar plana, adquiere un considerable volumen, conseguido mediante una sinuosa y marcada línea que articula todo su cuerpo. Parte ésta de la cabeza, literalmente caída hacia delante, lo que contrasta con el serpentinato trayecto del eje corporal que dibujan los hombros, la espalda, las caderas y las piernas. Ello nos hace suponer que su autor no sólo tuvo en cuenta la visión habitual de la imagen de frente, sin duda, también fue consciente de una percepción de perfil, que todo indica que cuidó con especial esmero. (Figura 5).

En cualquier caso, lo más llamativo de la obra es que, junto a lo anterior, evidencia un marcado gusto por mostrar ciertos detalles de desgarradora crudeza, particularmente la herida del hombro izquierdo, que cabe suponer producida por el acarreo de la cruz, y, sobre todo, las dos formidables aperturas de la espalda, completamente descarnadas hasta mostrar las costillas y el propio contenido de la caja torácica, en las que no nos cansamos de insistir. En este sentido, no se trata de un caso único, ya que el hecho de mostrar tan enormes heridas es algo habitual en la imaginería virreinal novohispana, siendo incluso frecuente que las referidas costillas, más que talladas en la madera, se hiciesen mediante la aplicación de huesos de animales, como en el caso que nos ocupa ${ }^{6}$.

Tan fabuloso rasgo de patetismo nos parece vinculable, más que a fórmulas arcaizantes habitualmente atribuidas a la escultura devocional virreinal

${ }^{5}$ GÓMEZ PIÑOL, Emilio: "Tres esculturas novohispanas...”, op. cit., pp. 7 y 8. Véase también, de este mismo autor, "Sentimiento religioso e imágenes del crucificado en al arte hispanoamericano del siglo XVI", en Signos de evangelización. Sevilla y las hermandades en Hispanoamérica. Sevilla, 1999, pp. 63-94.

${ }^{6}$ Véanse otros ejemplos muy similares en MAQUÍVAR, María del Consuelo: "La escultura en el Museo Nacional del Virreinato", en Escultura. Museo Nacional del Virreinato. México, 2007, p. 76. 
-particularmente novohispana-, a ancestrales atavismos indianos, que en el caso de Nueva España parece que se hunden en la desgarradora imaginería azteca. A este respecto no está de más recordar las esclarecedoras palabras de Moyssén, que señaló que en los angustiados cristos novohispanos la piedad y la bondad quedaron excluidas, de manera que hay que entenderlas como "imágenes regidas por una estética de lo tremendo, una estética del horror y del espanto cósmico de los dioses". A ello añade el citado historiador que fue en el realismo de estos iconos donde los indios se sintieron plenamente identificados con los españoles. De tal manera, es posible que en este patetismo de la imaginería novohispana "hayan intervenido viejos atavismos relacionados con los cultos de las religiones prehispánicas. No sabríamos decir hasta qué punto esto ha sido un hecho viable, pero sea o no, nada obliga a descartarlo del todo cuando se estudian las tremendas representaciones de los cristos sangrientos de este país, representaciones que en su realismo exacerbado superan a las obras de los escultores del barroco español"7.

Absolutamente certeras son las palabras del clásico historiador del arte mexicano, pero también cabría señalar que, aunque es cierto que el grado general de patetismo de la imaginería novohispana fue muy superior al de la española, cabe encontrar en esta última excepciones verdaderamente insuperables, como es el caso del Cristo de las Claras, venerado en el monasterio homónimo de la ciudad castellana de Palencia y que, más que una escultura, es un verdadero cadáver humano. Sin duda, se trata de un caso extremo, donde el pathos resulta absoluto, como recientemente ha analizado in extenso Rodríguez de la Flor ${ }^{8}$. De igual manera, no está de más traer a colación otro caso excepcional, como el conocidísimo Crucificado de Matthias Grünewald que centra el retablo de Isenheim y cuya superficie cutánea está absolutamente lacerada9 .

Pero volviendo a los "cristos sangrantes" mexicanos, hay que referir que en fechas recientes y en relación al famoso Cristo del Árbol del Museo Nacional del Virreinato, Portús ha dado una nueva interpretación al respecto, en la que destaca el interés de los mismos por aflorar "fenómenos y sentimientos fuertemente incardinados en la mentalidad de la sociedad mexicana". A ello añade el referido historiador que cabe interpretarlos como "una especie de límite o frontera donde confluyen conceptos esenciales, como los de la relación entre materia y forma, entre belleza y expresión, y entre arte y religión". Relaciona también este tipo de imágenes con la

${ }^{7}$ MOYSSÉN, Xavier: México, Angustia de sus cristos. México, 1967, pp. VIII y XVXVI respectivamente.

${ }^{8}$ RODRÍGUEZ DE LA FLOR, Fernando: De Cristo. Dos fantasías iconológicas. Madrid, 2011, véase particularmente la p. 148 y ss.

${ }^{9}$ HUYSMANS, Joris Karl: Grünewald: el retablo de Isenheim. Madrid, 2010. 
tradición iconográfica de las imágenes sagradas creadas por la naturaleza y, en última instancia, por Dios ${ }^{10}$.

Por otra parte, el agudo sentido devoto de nuestro Cristo en modo alguno hay que asociarlo automáticamente con "lo popular", más bien la escultura que analizamos cabe inscribirla en el marco de "lo culto" por su gran nivel técnico y artístico. A pesar de ello, se ha entendido tradicionalmente que estas imágenes son de escaso interés artístico y por ello han sido calificadas despectivamente como populares $^{11}$. El caso que tratamos evidencia que tal aserto no siempre se cumple.

La variedad de esculturas similares a la que en esta ocasión estamos analizando alcanza su punto culminante, más que en los muchos e interesantes casos conservados en el Museo Nacional del Virreinato de Tepotzotlán ${ }^{12}$, en la sorprendente colección que el Museo de Arte Colonial de Morelia atesora. Formada por más de cien ejemplares de Cristo Crucificado, la variedad que cabe predicar de todos ellos parece difícil de reducir a sistema. Aunque lógicamente comparten iconografía, así como su pequeño formato y procedencia novohispana, su variedad técnica, formal y material es verdaderamente sorprendente. Esta asombrosa galería de Crucificados prueba la vocación expresiva y cruenta de la imaginería novohispana a la que antes hicimos referencia. En clara relación con el Cristo sanluqueño que venimos analizando, en el referido museo michoacano son frecuentes las esculturas con ojos de vidrio y piezas de hueso que evocan en inmensa heridas las costillas del Señor, dándose la circunstancia de que algunos hasta cuentan con uñas, en ocasiones hechas con cañones de plumas. Es más, en un caso concreto, la imagen deja ver hasta el corazón a través de la herida producida por la lanza. En el ejemplo sanluqueño, como indicamos, sobre las heridas encontramos cuero rojo, lo cual sería comparable con los trozos de concha con los que cuentan algunos de los cristos de Morelia. Sin duda, la comparación del que estudiamos en esta ocasión con los michoacanos no hace más que confirmar su evidente procedencia novohispana ${ }^{13}$. (Figura 6).

No se trata realmente todo ello de una particularidad escultórica. En este sentido, cabe traer a colación figuras pictóricas que combinan tan desgarradora expresividad con un marcado carácter culto, lo cual no hace más que demostrar la general aceptación de la sociedad novohispana de estas patéticas imágenes. Así, por

10 PORTÚS, Javier: "171. El Cristo del árbol”, en BERCHEZ, Joaquín (dir.): Los Siglos de Oro en los virreinatos de América (1550-1700). Madrid, 1999, pp. 406-407.

${ }^{11}$ Así se dice en GARCÍA-ABASOLO, Antonio: "Cristos mexicanos y devoción popular en Andalucía", en PELÁEZ DEL ROSAL, Manuel (ed.): El franciscanismo en Andalucía. Conferencias del I curso de verano sobre el franciscanismo en Andalucía (Priego de Córdoba, 7 a 12 de agosto de 1995). Córdoba, 1997, pp. 139-145, véase en concreto la 139.

${ }_{12}$ Acerca de ellos véase Escultura ... op. cit, en particular, el catálogo del museo.

13 Véase MAQUívAR, María del Consuelo (coord.): Cristos. Escultura del Museo de Arte Colonial de Morelia. Morelia, 2010. 
poner un ejemplo significativo y aún por estudiar in extenso, cabría citar el Ecce Homo del Museo de Guadalupe, Zacatecas. Se trata de un óleo sobre lienzo de gran calidad y que en el museo es tenido por anónimo novohispano del siglo XVIII ${ }^{14}$. Se da la circunstancia de que en el anverso de dicho soporte aparece la imagen pintada frontalmente y con un carácter considerablemente clásico, mientras que en su reverso aparece la espalda del Ecce Homo completamente descarnada, de manera que se ven claramente sus costillas y hasta buena parte de su columna vertebral. (Figuras 7 y 8 ).

Este último detalle, una concepción frontal relativamente comedida sensorialmente y una visión trasera de desgarrador dramatismo, nos hace intuir que nuestra escultura pudo estar pensada para un doble nivel de percepción, uno primero superficial y otro más profundo e intenso. Sin duda, se trata de un asunto digno de futuros estudios.

Nada sabemos de nuestra escultura, aparte de su procedencia novohispana por razones formales y conceptuales. El hecho de haber aparecido en la localidad gaditana de Sanlúcar de Barrameda no puede resultar extraño debido a las intensas relaciones de tal población tuvo históricamente con América ${ }^{15}$. Es fácil suponer que en las casas de cargadores de Indias que aún se conservan en la localidad existan otras obras similares a esta, al igual que en otras poblaciones de la bahía gaditana. Incluso, perfectamente a la vista se conservan otras imágenes de similares características que aún no han sido estudiadas con la profundidad que requieren. Aunque no nos vayamos a ocupar de él en esta ocasión, no queremos dejar de mencionar el extraordinario Crucificado que se custodia en la sacristía de la parroquia del Rosario de Cádiz. Se trata de una obra claramente novohispana, muy relacionada con la que ahora analizamos, siendo de mayor tamaño y coincidiendo en un mismo sentido dramático, ya que también tiene su cuerpo cubierto de numerosas heridas y regueros de sangre.

Por lo que se refiere a la cronología de nuestro Crucificado de Sanlúcar, suponemos que se trata de una obra de la segunda mitad del siglo XVIII. Un primer y evidente signo que apunta en tal sentido es el titulus de la cruz, de asimétrico perfil rococó. Las rocallas que enmarcan las iniciales de Jesús Nazareno Rey de los Judios evocan claramente al referido motivo decorativo de origen francés,

${ }^{14}$ Así lo indica la cartela que acompaña a la obra. Agradecemos a Violeta Tavizón, subdirectora del museo guadalupano, la información que amablemente nos ha suministrado sobre esta interesante pintura digna de un estudio más detallado que el breve apunte que de ella realizamos en esta ocasión.

${ }^{15}$ Ninguna tradición familiar oral ni otros datos al respecto han podido ser aportados por sus actuales propietarios, a los que agradecemos sus facilidades para hacer este estudio.

LABORATORIO DE ARTE 28 (2016), pp. 305-318, ISSN 1130-5762

e-ISSN 2253-8305 - DOI http://dx.doi.org/10.12795/LA.2006.i.01.16 
desarrollado en la platería hispánica en la segunda mitad de dicha centuria ${ }^{16}$. La policromía aporcelanada de la obra apunta la misma cronología, lo mismo que el carácter apolíneo del cuerpo de Cristo, como si ya se hiciese eco de los postulados académicos, aunque el referido contraste entre cuerpo y cabeza y el expresionismo ya referidos no dejan lugar a dudas de que se trata aún de una obra de claro sentido barroco.

En cuanto a la autoría de esta pieza, resulta imposible, siquiera a título de hipótesis, plantear algún taller del que pudiera haber salido. Es muy poco aún lo que se conoce de los escultores novohispanos y de sus talleres, sólo ciertos encargos de los mismos para retablos han permitido hasta ahora al menos destacar algunos nombres, a los que todavía habría que sumar piezas exentas, que en la inmensa mayoría de los casos conservados se encuentran en el limbo del anonimato ${ }^{17}$.

Este tipo de objetos fácilmente transportables, al igual que imágenes de pasta de caña, biombos, piezas de plata, cuadros de la Virgen de Guadalupe en número ingente y ornamentos variadísimos fueron los que en mayor cantidad llegaron desde los virreinatos americanos a la metrópoli. Muchos de ellos, donaciones de indianos enriquecidos, se encuentran aún sin identificar como obras americanas. Sin duda, el afloramiento de estas obras permitirá en un futuro que esperamos próximo hacernos una idea más cabal que la actual del verdadero trasiego humano y, por supuesto, de obras de arte que hubo entre ambas orillas del Atlántico durante el período virreinal.

Fecha de recepción: 3 de septiembre de 2015.

Fecha de aceptación: 20 de noviembre de 2015.

${ }^{16}$ Son muchísimas y conocidas las piezas de plata de esta época existentes en España, en gran medida llegadas desde América merced a legados testamentarios. Por poner un ejemplo particularmente relacionado con el que esta ocasión tratamos, al ser de igual estilo y cronología, remitimos a la aureola del San Antonio de la parroquia de Trigueros, Huelva. Véase al respecto PALOMERO PÁRAMO, Jesús M.: Plata labrada de Indias. Los legados americanos a las iglesias de Huelva. Huelva, 1992.

17 Un caso significativo es el de Isidoro Vicente Balbás y los retablos y esculturas de la iglesia de Santa Prisca de Tasco. Véanse al respecto VARGAS LUGO, Elisa, La iglesia de Santa Prisca de Tasco, México, Instituto de Investigaciones Estéticas, 1982 y Santa Prisca restaurada. Madrid, Turner, 1990. 


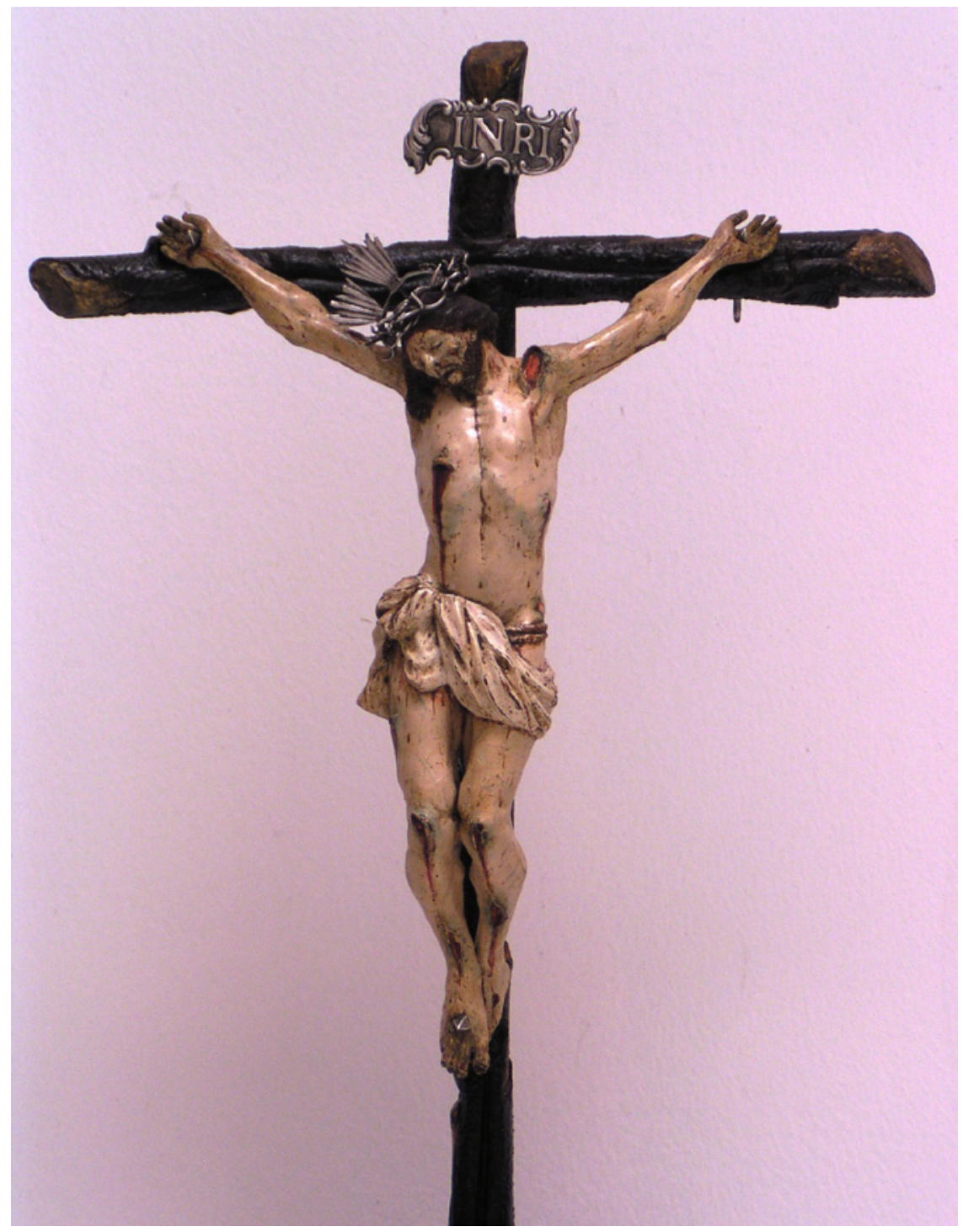

Figura 1. Cristo Crucificado, anónimo novohispano, segunda mitad del siglo XVIII, colección particular de Sanlúcar de Barrameda, Cádiz. 


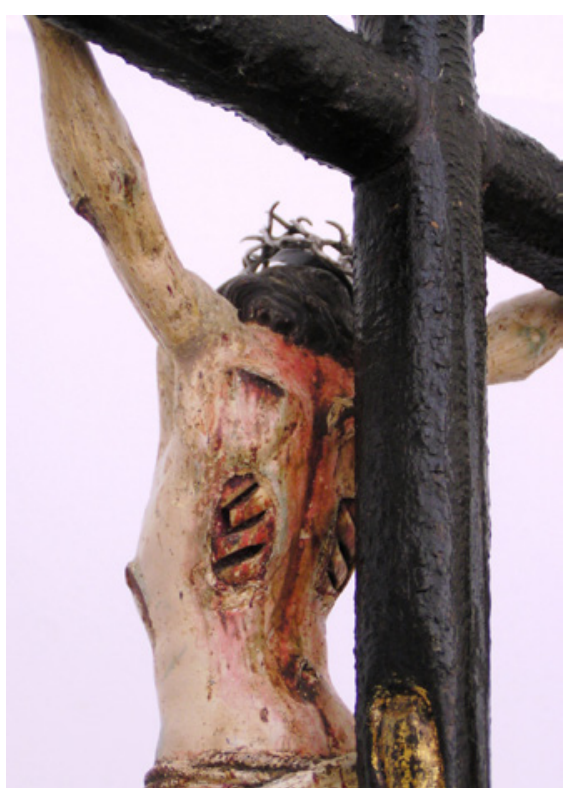

Figura 2. Cristo Crucificado, anónimo novohispano, segunda mitad del siglo XVIII, colección particular de Sanlúcar de Barrameda, Cádiz, detalle.

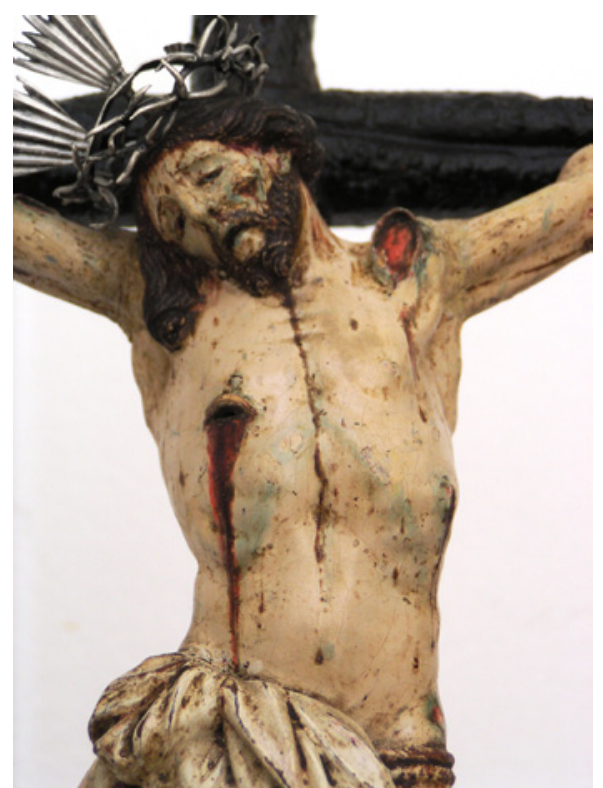

Figura 3. Cristo Crucificado, anónimo novohispano, segunda mitad del siglo XVIII, colección particular de Sanlúcar de Barrameda, Cádiz, detalle.

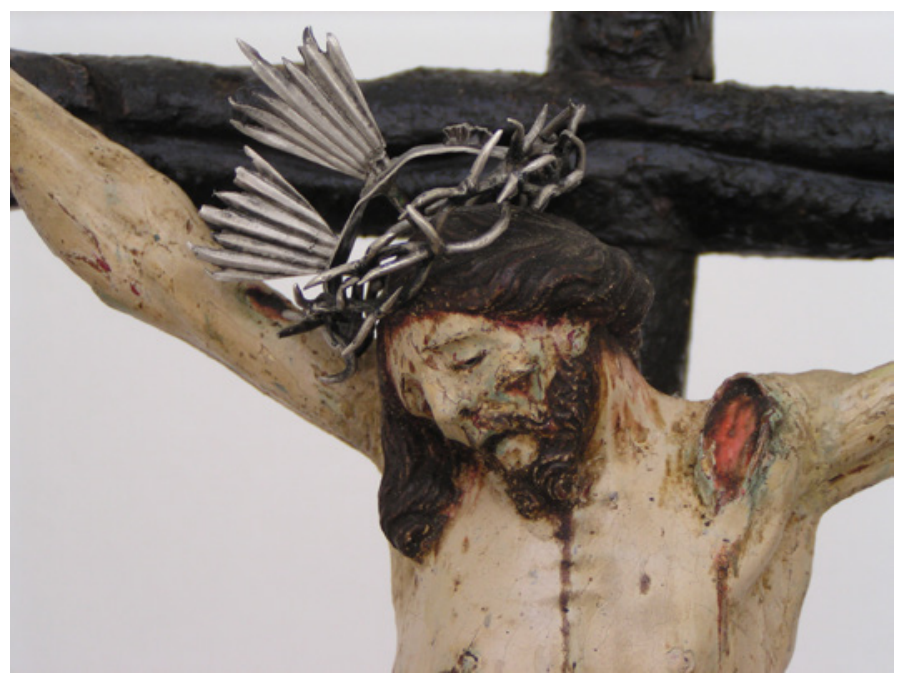

Figura 4. Cristo Crucificado, anónimo novohispano, segunda mitad del siglo XVIII, colección particular de Sanlúcar de Barrameda, Cádiz, detalle. 


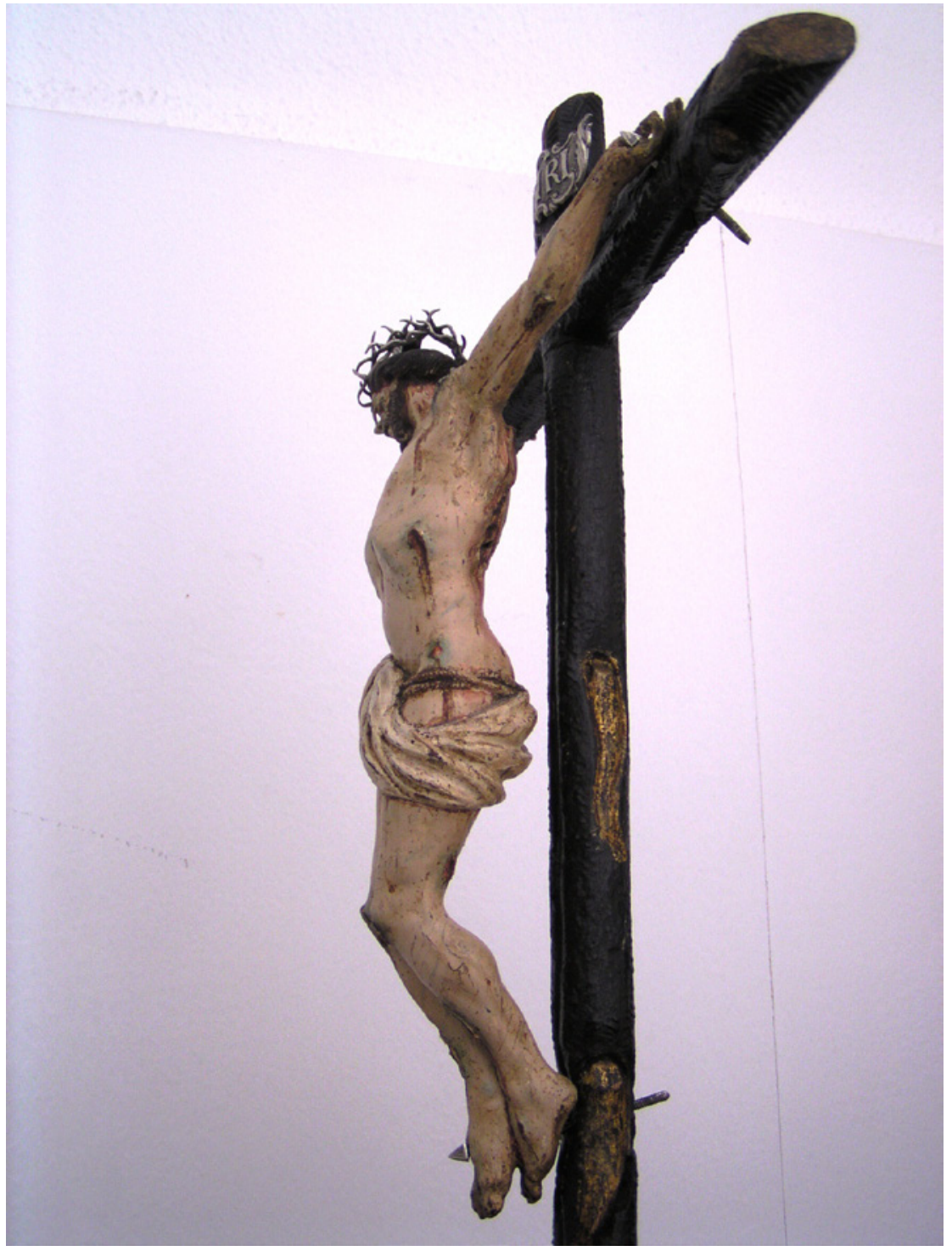

Figura 5. Cristo Crucificado, anónimo novohispano, segunda mitad del siglo XVIII, colección particular de Sanlúcar de Barrameda, Cádiz. 
Figura 6. Cristo Crucificado, anónimo novohispano, ¿siglo XVIII?, Museo de arte colonial de Morelia, México, detalle.

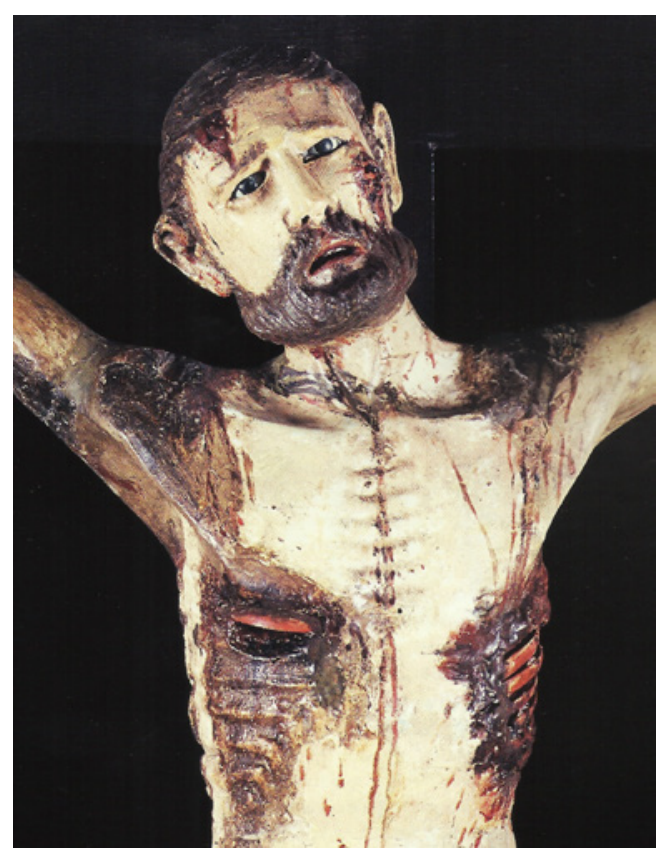

Figura 7. Ecce Homo, anónimo novohispano, siglo XVIII, Museo de Guadalupe (Zacatecas), México, anverso.

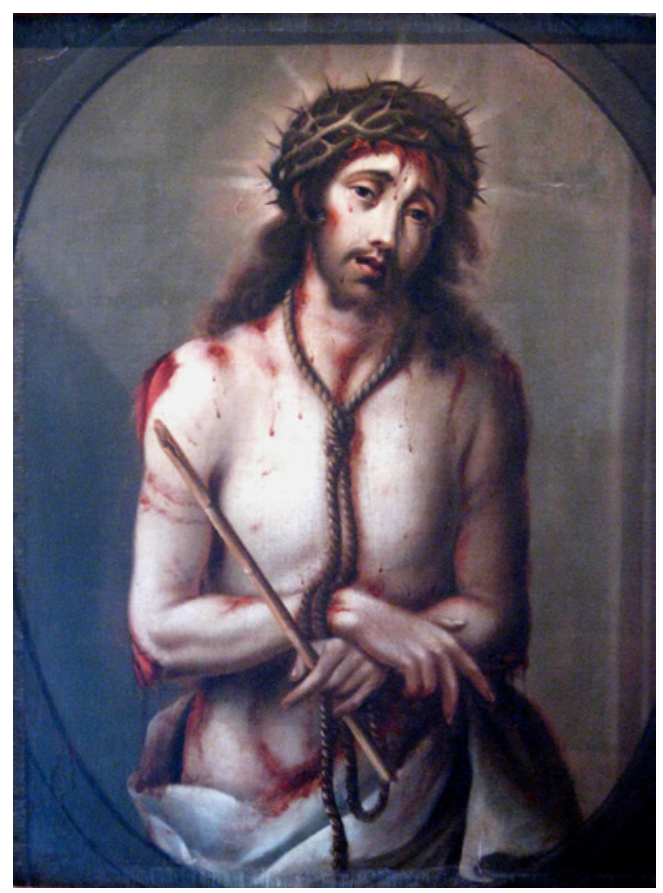

LABORATORIO DE ARTE 28 (2016), pp. 305-318, ISSN 1130-5762 e-ISSN 2253-8305 - DOI http://dx.doi.org/10.12795/LA.2006.i.01.16 


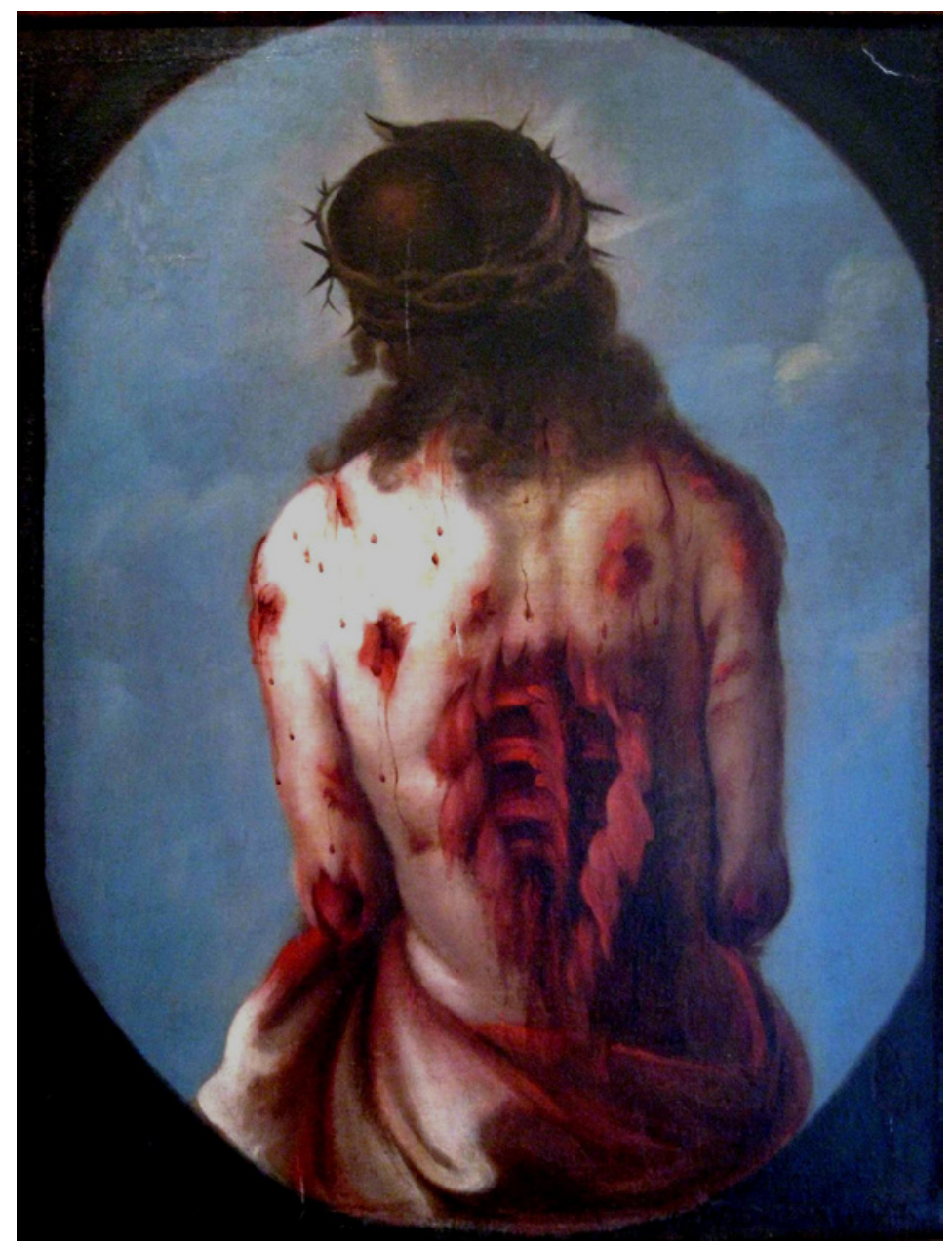

Figura 8. Ecce Homo, anónimo novohispano, siglo XVIII, Museo de Guadalupe (Zacatecas), México, reverso. 